\title{
Preface: Symposium on Stegosauria proceedings
}

\author{
An international conference on stegosaur finds of the world organized \\ by the Sauriermuseum Aathal (8th and 9th June 2009, Aathal, Switzerland)
}

\author{
Jean-Paul Billon-Bruyat • Daniel Marty
}

Published online: 4 September 2010

(C) Swiss Geological Society 2010

The Stegosauria, the plated dinosaurs, are medium to largesized quadrupedal herbivorous ornithischians. They figure prominently in the history of dinosaur palaeontology because of their bizarre appearance: large body, tiny skull with small crenulated teeth, hind legs taller than the forelegs, two rows of dorsally projecting erect dermal plates along the back and tail, and spikes at the end of the tail (Carpenter and Galton 2001). The most famous genus commonly used for toys, movies, and known by many children (and adults!) is Stegosaurus ("roof lizard"). It was named as early as 1877 by O. C. Marsh from fossils of the Late Jurassic of western North America. Most of the major features of our current view of Stegosaurus were already in place when O. C. Marsh (1891) published the first skeletal reconstruction. Nonetheless, from that time on, plated dinosaurs have been the leaststudied dinosaurs and their incredible diversity has only recently been recognized (Carpenter 2001). Meanwhile, stegosaurs have been recovered from all northern hemisphere continents and Africa. They are temporally restricted to the Middle Jurassic to Early Cretaceous (Galton and Upchurch 2004; Maidment et al. 2008), with no definitive stegosaurian material known with confidence in younger sediments from anywhere in the world. In Switzerland, only one stegosaur bone (a proximal end of a femur) is known so far (Meyer and Hunt 1998).

Since 1990, the Sauriermusem Aathal carries out excavations in the Upper Jurassic Morrison Formation of the Howe-Stephens and Howe-Scott quarries (Howe Ranch, Big Horn Mountains, Wyoming, USA) (Ayer 2000).

J.-P. Billon-Bruyat $(\bowtie) \cdot D$. Marty

Paléontologie A16, Section d'archéologie et paléontologie,

Office de la Culture, Hôtel des Halles, P.O. Box 64,

2900 Porrentruy 2, Switzerland

e-mail: jean-paul.billon@palaeojura.ch
Besides the famous discoveries of specimens of Allosaurus, Diplodocus, or Camarasaurus some of the most complete stegosaur skeletons of the world were also excavated over the years. They include four specimens of stegosaurids referred to cf. Stegosaurus armatus and Hesperosaurus mjosi, and nicknamed "Sarah", "Moritz" (Fig. 1), "Lilly", and "Victoria" (Siber and Möckli 2009). The latter specimen is nearly complete and includes an exquisitelypreserved skull, several hand-sized patches of skin impressions, and several pronounced pathologies.

Since many years Hans Jakob "Kirby" Siber, director of the Sauriermuseum Aathal, undertakes great efforts to make accessible the museum collection for scientific research, and it was the Sauriermuseum, which organized and financed the "Symposium on Stegosauria". The main purpose of the "Symposium on Stegosauria" was to bring together leading stegosaur specialists (http://www.sauriermuseum.ch/Dstego symp.htm) from different parts of the world (Canada, Denmark, France, Germany, Japan, Portugal, Spain, Switzerland, UK, USA), in order to discuss recent advances and future directions in stegosaur research. Another purpose was to study and discuss the extraordinary Aathal specimens, some of which are now on display in a special exhibition of the Sauriermuseum.

During the symposium, 19 talks were given, covering a broad spectrum of research on stegosaur palaeontology such as: history of discoveries and research, new finds, taxonomy and phylogeny, bone histology and ontogeny, biomechanics, ichnology, taphonomy, and palaeoecology. Martin Sander (University of Bonn) chaired the sessions and there was plenty of time for interesting and animated discussions.

Eight contributions are presented in the proceedings, a number of which re-evaluate historical finds, describe new finds, highlight the difficulties in the-palaeontologicalspecies concept of stegosaurs, and discuss taxonomy and 


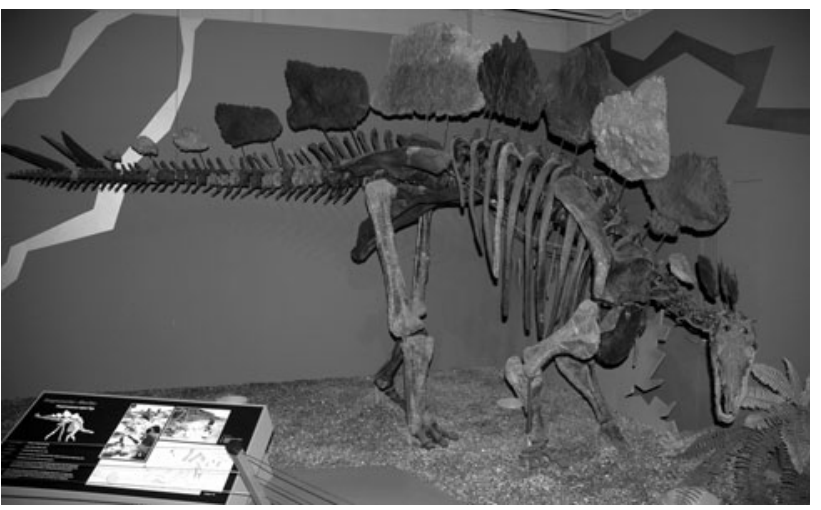

Fig. 1 Skeletal reconstruction of the stegosaurid Hesperosaurus mjosi (specimen "Moritz") from the Late Jurassic of Wyoming (USA) as exhibited in the Sauriermuseum Aathal. Total body length is approximately $4.5 \mathrm{~m}$. Photograph by J.-P. Billon-Bruyat

phylogenetic relationships. In this way, the International Commission on Zoological Nomenclature will be petitioned to designate Stegosaurus stenops MARSH 1887 as the new type species of Stegosaurus MARSH 1877. Elsewhere, stegosaurian skin impressions are described for the first time from North America, as well as the first case of preservation of an impression of the integument that covered the dorsal plates. Both have been found closely associated with bones of the specimen "Victoria" (H. mjosi). The other papers apply state-of-the-art methodologies and focus on palaeobiological issues. The role of the internal vascularity of stegosaur dermal plates for thermoregulation is analyzed with X-ray computed tomography and infrared thermographic imaging and by comparison with osteoderms of recent alligators. To better understand the feeding habits of Stegosaurus, the bite mechanics were reconstructed using Finite Element Analyses on three-dimensionally modelled teeth. Finally, the biomechanics of Kentrosaurus from the Upper Jurassic Tendaguru Formation were assessed with a Computer Aided Design (CAD) analysis on a digital skeleton created from high-resolution laser scans of the bones.

In conclusion, stegosaur research is alive and new important discoveries, such as those of the Sauriermuseum Aathal in Wyoming (USA) or recently those in Portugal (Mateus et al. 2009) and in Spain (Cobos et al. 2010) are showing that stegosaurs were more diverse and widespread than previously thought. Future work will focus both on the detailed analysis of known material and on the discovery of new fossils such as skulls with complete tooth rows. Skulls are extremely rare and usually preserved in such a way that it is hard to examine the teeth in detail, precluding - at the time being - a precise description of the stegosaur dentition.

We would like to heartily acknowledge Hans Jakob "Kirby" Siber-laureate of the Prize Amanz Gressly
2010 of the Swiss Palaeontological Society-and the Sauriermuseum Aathal and its staff for organizing and financing the symposium, hosting of the invited speakers, and for financing additional pages of the present proceedings. We also thank the Institute and Museum of Palaeontology of the University of Zürich and the Sauriermuseum Frick for receptions during the fieldtrip. Finally, these proceedings articles would not have been possible without the great help of the reviewers: P. Barrett, K. Carpenter, P. J. Currie, P. M. Galton, D. Henderson, S. C. R. Maidment, X. Pereda Suberbiola, E. Rayfield, R. Redelstorff, D. Schwarz-Wings, W. Sellers, P. Upchurch, M. Vickaryous and two anonymous reviewers.

Finally, open your eyes on the field to find new "punk dinos"!

Porrentruy, 22nd July 2010

Jean-Paul Billon-Bruyat (Associate Editor of SJG)

Daniel Marty (Editor of SJG)

Proceedings articles in the present issue of the Swiss Journal of Geosciences:

Billon-Bruyat, J.-P., Mazin, J.-M., \& Pouech, J.: A stegosaur tooth (Dinosauria, Ornithischia) from the Early Cretaceous of southwestern France.

Carpenter, K.: Species concept in North American stegosaurs.

Christiansen, N. A., \& Tschopp, E.: Exceptional stegosaur integument impressions from the Upper Jurassic Morrison Formation of Wyoming.

Farlow, J. O., Hayashi, S., \& Tattersall, G. J.: Internal vascularity of the dermal plates of Stegosaurus (Ornithischia, Thyreophora).

Galton, P. M.: Species of plated dinosaur Stegosaurus (Morrison Formation, Late Jurassic) of western USA: new type species designation needed.

Maidment, S. C. R.: Stegosauria: A historical review of the body fossil record and phylogenetic relationships.

Mallison, H.: CAD assessment of the posture and range of motion of Kentrosaurus aethiopicus HeNNIG 1915.

Reichel, M.: A model for the bite mechanics in the herbivorous dinosaur Stegosaurus (Ornithischia, Stegosauridae).

\section{References}

Ayer, J. (2000). The Howe Ranch Dinosaurs (96 pp). Aathal, Switzerland: Sauriermuseum Aathal.

Carpenter, K. (Ed.). (2001). The Armored Dinosaurs (526 pp). Bloomington: Indiana University Press.

Carpenter, K., \& Galton, P. M. (2001). Othniel Charles Marsh and the myth of the eight-spiked Stegosaurus. In K. Carpenter (Ed.), The 
Armored Dinosaurs (pp. 76-102). Bloomington: Indiana University Press.

Cobos, A., Royo-Torres, R., Luque, L., Alcalá, L., \& Mampel, L. (2010). An Iberian stegosaurs paradise: The Villar del Arzobispo Formation (Tithonian-Berriasian) in Teruel (Spain). Palaeogeography, Palaeoclimatology, Palaeoecology, 293, 223-236.

Galton, P. M., \& Upchurch, P. (2004). Stegosauria. In D. B. Weishampel, et al. (Eds.), The Dinosauria (2nd ed., pp. 343-362). Berkeley: University of California Press.

Maidment, S. C. R., Norman, D. B., Barrett, P. M., \& Upchurch, P. (2008). Systematics and phylogeny of Stegosauria (Dinosauria: Ornithischia). Journal of Systematic Palaeontology, 6, 367-407.

Marsh, O. C. (1877). A new order of extinct reptilia (Stegosauria) from the Jurassic of the Rocky Mountains. American Journal of Science 3rd Series, 14, 34-35.
Marsh, O. C. (1891). Restoration of Stegosaurus. American Journal of Science 3rd Series, 42, 179-182.

Mateus, O., Maidment, S. C. R., \& Christiansen, N. A. (2009). A new long-necked 'sauropod-mimic' stegosaur and the evolution of the plated dinosaurs. Proceedings of the Royal Society of London $B, 276,1815-1821$.

Meyer, C. A., \& Hunt, A. P. (1998). The first stegosaurian dinosaur (Ornithischia: Thyreophora) from the Upper Jurassic of Switzerland. Neues Jahrbuch für Geologie und Paläontologie Monatshefte, 1998, 141-145.

Siber, H. J., \& Möckli, U. (2009). The stegosaurs of the Sauriermuseum Aathal (56 pp). Aathal, Switzerland: Sauriermuseum Aathal. 